\title{
Concept of Genetic Transmission of the 'Essence of Salvation' in Ethiopian Church and Its Reminiscence in Islam
}

\author{
Serge A. Frantsouzoff \\ Institute of Oriental Manuscripts, Higher School of Economics (St. Petersburg), \\ St. Petersburg State University \\ serge.frantsouzoff@yahoo.fr
}

\begin{abstract}
The 68th chapter of the Ethiopian dynastic treatise Kabrä nägäst 'the Nobility of the Kings' is of considerable interest due to the occurrence of the term mädhänit interpreted either as 'Savior' (in the feminine!) or as 'Salvation'. The contents of that chapter is focused on a specific 'essence of Salvation' ('onq wä bahrəy, literally 'mother-of-pearl') created 'in the abdomen of Adam' and transmitted from generation to generation. It should be noted that in medieval Ethiopian Christian theology the term bahroy 'pearl' denoted the Second Hypostasis represented in the unity of His nature. A parallel to such a concept of 'Salvation' transfer was found in Islamic tradition, viz. in legends about the emission of light from 'Abdallāh, Muhammad's father, which gave evidence of his engagement in procreation of a future prophet. Similar ideas appeared to influence the early Shī'ite doctrine.
\end{abstract}

\section{Keywords}

medieval Ethiopia - dynastic treatise Kabrä nägäśt - Ethiopian Church - Christian theology in Ethiopia - Savior and Salvation - Islamic tradition - origin of the prophet Muhammad

* This article is an output of a research project implemented as part of the Basic Research Program at the National Research University Higher School of Economics (HSE). 
The Ethiopian dynastic treatise Kabrä nägäst 'the 'Nobility of the Kings' contains some peculiar theological ideas and concepts. The story about the Ark of the Covenant identified with the real Zion constitutes the core of its plot. The opening lines of the 17 th chapter state that the "Tabernacle of the Law

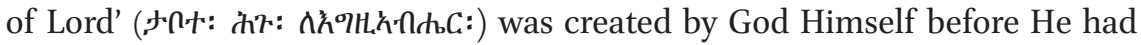
established the heavens and according to His good will should become the

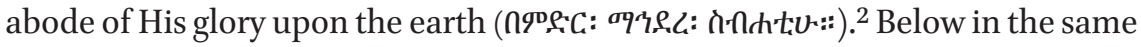
chapter a strict distinction is made between the spiritual original of the Ark of

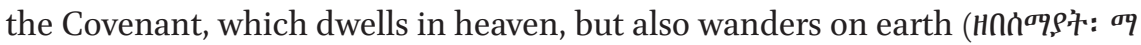

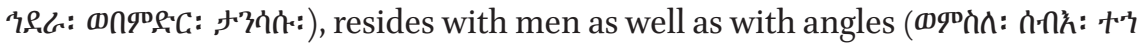

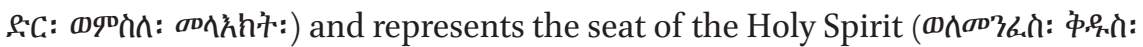
${ }^{a y}$ ' $\left., P, C:::\right),{ }^{3}$ and its copy, that was made of wood, which is not worm-eaten, and overlaid with pure gold by Moses upon God's order. ${ }^{4}$ Among numerous epithets attributed to this marvelous object the active participle transformed into

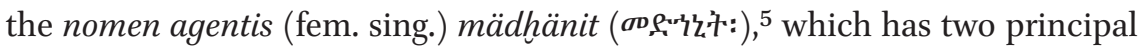
meanings, viz. 'Savior' and 'Salvation', is to be noted. The handmade Ark of the Covenant, which became the main relic of the people of Israel, proved to be mystically connected with its heavenly prototype and therefore became endowed with supernatural power.

When the King Solomon found out that this sacred object had been stolen by his elder son David, known in Ethiopian tradition as Mənilək I, and failed to get it back, he addressed a complaint to God, ${ }^{6}$ Who consoled him with a good message about the origin of the future Savior of the world from his seed. This story is told in detail in the 68th chapter of the treatise Kabrä nägäst entitled

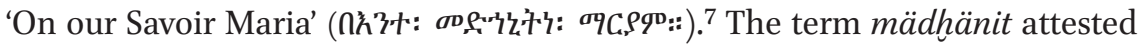

1 On its general characteristics and the dating of its final version from the early forties of the 14th century AD see: S. Frantsouzoff, "On the Dating of the Ethiopian Dynastic Treatise Kabra nagaśt: New Evidence", Scrinium. Journal of Patrology and Critical Hagiography, 12. 2016, pp. 20-24.

2 Kebra Nagast:Die Herrlichkeit der Könige, hrsg. und mit deutscher Übersetzung versehen von C. Bezold (Abhandlungen der Königlichen Bayerlichen Akademie der Wissenschaften, I. Klasse, XXIII. Bd, I. Abt.), München, 1905, S. 9, Kol. 1.16-18, 2.5-7.

3 Kebra Nagast ..., S. 9, Kol. 2.10-11, 13.

4 Kebra Nagast ..., S. 9, Kol. 1.18-2.5.

5 Kebra Nagast ..., S. 9, Kol. 2.13.

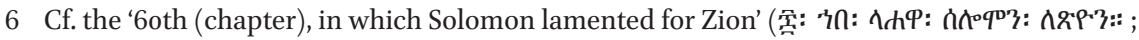
Kebra Nagast ..., S. 66, Kol. 1.23-70, Kol. 2.6).

7 Kebra Nagast ..., S. 82, Kol. 1.5. Cf. C. Bezold's translation: 'Von unserer Erlöserin Maria' (Ibid., S. 65). The interpretation of that title as 'Concerning Mary, Our Lady of Salvation' (The Queen of Sheba and her only son Menyelek ... A complete translation of the Kebra nagast with introduction by E.A. Wallis Budge, London; Boston (Mass.), 1922, p. 95) seems rather figurative. 
here is ambiguous: in the title cited above it is applied to the Virgin Mary, while in the text of the chapter it designates a specific 'essence of Salvation': "Your salvation was created in the abdomen of Adam like the mother-of-pearl before

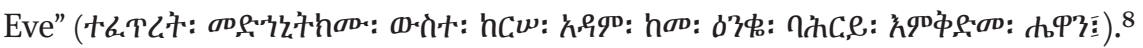
From Adam it passed not to Cain, but to Seth, who was free from the sin of fratricide, ${ }^{9}$ and then was transmitted mostly through the firstborn sons, albeit with several deviations from that rule: for instance, from Abraham this essence came to Isaac, not to Ismael, from Isaac - to Jacob, not to Esau, from Jacob - to the innocent Judah, not to the erring Reuben, and from Solomon - to Roboam (Rehoboam), not to David / Mənilək. Finally it should reach St. Joachim, the father of Our Lady..$^{10}$ That idea of transfer of the 'essence of Salvation' through ancestors in the paternal line has a parallel in the Talmudic embryological concept reflected also in some Quranic passages, which assigns the exclusive part in procreation to the male breeder. ${ }^{11}$

The comparison of that 'essence' with the 'mother-of-pearl' ('anqw $\ddot{a}$ bahrray) reminds the term bahray 'pearl' in Ethiopian Christian theology, where it denotes the single nature of Christ in full accordance with Monophysite doctrine. ${ }^{12}$ However, the difference in the use of the word bahray in the dynastic treatise and in theological works is fundamental: in the first case it renders one of the properties created by God at the very beginning of the world for Jesus Christ as a human being, while in the second it describes the Second Hypostasis in the unity of His nature, eternal and uncreated. At the same time the treatise Kabrä nägäśt composed by scholars, who undoubtedly were well-versed in theological issues, cannot be labeled as profane. In all probability, their literal adherence to some crucial Monophysite principles, such as the denial of the human nature of Christ, played a malicious joke with them and as a result they became inclined to admit the material existence of an enigmatic 'essence of Salvation' as His integral quality and its physical (even physiological) transmission from generation to generation.

8 Kebra Nagast ..., S. 82, Kol. 1.9-11. The use of this term with regard to the Ark of the Convenant (see $n .5$ above) appears to be mostly metaphoric.

9 The mention of Seth in that genealogical chain is noteworthy in consideration of the particular place he took in Gnostic believes.

$10 \quad$ Kebra Nagast ..., S. 82, Kol. 1.11 - 83, Kol. 2.1.

$11 \quad$ I.N. Vinnikov, "Koranicheskie zametki” (Quranic notes), in: Issledovanija po istorii kul'tury narodov Vostoka. Sbornik v chest' I.A. Orbeli (Studies in the history of culture of the peoples of the Orient. Collected works in honour of I.A. Orbeli), Leningrad, 1960, p. 311. istorii Efiopii. II. Bogoslovskie spory v efiopskoj tserkvi” (Several pages from the ecclesiastic history of Ethiopia. II. Theological disputes in Ethiopian Church), Khristianskoe chtenie (Christian Reading), 1888, $\mathrm{n}^{\circ}$ 11-12, pp. 787-788: n. 2. 
A certain parallel to such concept was discovered in Islamic tradition in connection with two legendary stories on the Prophet's origin, viz. on his father's marriage, which go back to Ibn Ishạa , but are conserved only in the annals of al-Tabarī. According to the first of them, before 'Abd al-Mutțalib decided to marry his youngest son 'Abdallāh, he sacrificed ten camels to Hubal; then he went to Wahb b. 'Abd Manāf b. Zuhrah, the leading man of the Banū Zuhrah in age and eminence at that time, taking 'Abdallāh by the hand. "It is alleged that he passed by a woman of the Banū Asad called Umm Qattāl bt. Nawfal b. Asad b. 'Abd al-'Uzzā, the sister of Waraqah b. Nawfal b. Asad, she was by the Ka'bah. When she looked at his face she said, "Where are you going, 'Abdallāh?" "With my father," he said. She said, "I have for you as many camels as were slaughtered for you, so sleep with me now." "My father is with me," he replied, "and I cannot oppose his wishes or leave him."” Directly after this occasional encounter 'Abd al-Mutțalib brought his youngest son to Wahb b. 'Abd Manāf and married him to Äminah, the daughter of Wahb, "who was then the most excellent woman in Quraysh as regards genealogy and status ... It is alleged that he consummated his marriage to her there as soon as he married her, that he lay with her and that she conceived Muhammad, then he left her presence and came to the woman who had propositioned him, and said to her, "Why do you not make the same proposition to me today which you made to me yesterday?" She replied, "The light (al-nür) which was with you yesterday has left you, and I have no need of you today." She had heard [about this] from her brother Waraqah $b$. Nawfal, who was Christian and had studied the scriptures; he had discovered that a prophet from the descendants of Ismāill was to be [sent] to this people; this had been one of the purposes of his study."13 In the annals of al-Tabari there is one more story with a similar plot, but her 'heroine' proved to be another woman "from the tribe of Khath'am called Fāțimah bt. Murr, a convert to Judaism from the people of Tabālah, who had read the scriptures." 14

13 Annales quos scripsit Aby Djafar Mohammed ibn Djarir at-Tabari, ed. M.J. de Goeje. Prima series. III, recensuit P. de Jong, Lugduni Batavorum, 1882-1885, pp. 1078-1079. For the English translation see: The History of al-Ṭabarī (Ta'rīkh al-rusul wa'l-mulūk). Vol. vi: Muhammad at Mecca, translated and annotated by W. Montgomery Watt and M.V. McDonald (Biblioteca persica, ed. by Ehsan Yar-Shater), Albany (N.Y.), 1988, pp. 5-6.

14 Annales quos scripsit ... at-Tabari, Prima series. III, pp. 1079-1081; The History of al-Tabari ... Vol. vI, pp. 7-8. It was Olga B. Frolova, who draw our attention to both stories (O.B. Forlova, "Tri poeticheskikh otryvka iz "Kitāb al-Agānī" (Three poetical fragments from the Kitāb al-Aghānī), Uchenye zapiski LGU (Memoirs of the Leningrad State University), $\mathrm{n}^{\circ}$ 403. Serija vostokovedcheskikh nauk (Series of Oriental Studies), vyp. (issue) 23. Vostokovedenie (Oriental Research), 7: Filologicheskie issledovanija (Philological Studies), 1980, 
The idea of a specific 'prophetic' essence transmitted genetically appeared to be borrowed from one of the peripheral Eastern Christian or Judaeo-Christian sects to which Waraqah b. Nawfal supposed to belong. A notion of the transcendental nature of God and of divine manifestations seems to be alien even to the culturally advanced gentile, not to speak about the peoples of the late primitive society.

In this connection the generally accepted statements and conclusions about Neoplatonic roots of the Shīite, especially extreme Shīite, doctrine of 'Alī as the divinely appointed heir of Muhammad probably require a reconsideration in view of above-mentioned Christian or at least Monotheistic ideas on genetic transmission of 'essences' of Salvation and of prophetic dignity.

pp. 141-145). However, her attempt to deduce from them a conclusion on the existence of a kind of secret organization of the hunafă' (pre-Islamic Arabian God-seekers) is imbued with the spirit of conspirology and can hardly be accepted. 